\title{
Levamisole-induced leukocytoclastic vasculitis and neutropenia in a patient with cocaine use: An extensive case with necrosis of skin, soft tissue, and cartilage
}

\author{
Natasha Purai Arora, Tania Jain, Ravinder Bhanot and Suganthini Krishnan Natesan
}

\begin{abstract}
Levamisole-induced vasculitis is a relatively new entity in people who use cocaine. We describe a 44-year-old woman with a history of cocaine use who presented with a complaint of a painful rash of 2-3 month's duration on her extremities, cheeks, nose, and earlobes. She had not experienced fever, weight loss, alopecia, dry eyes, oral ulcers, photosensitivity, or arthralgia. Examination revealed tender purpuric eruptions with central necrosis on her nose, cheeks, earlobes, and extremities. Laboratory investigations revealed neutropenia, an elevated erythrocyte sedimentation rate (ESR), presence of lupus anticoagulant, low complement component 3 (C3), and presence of perinuclear anti-neutrophil cytoplasmic antibody ( $\mathrm{p}$-ANCA). A urine toxicology screen was positive for cocaine, and gas chromatography-mass spectrometry was positive for levamisole. Skin biopsy showed leukocytoclastic vasculitis and small vessel thrombosis. Necrotic lesions of the nose led to its self-amputation. Large bullae on the lower extremities ruptured, leading to wound infection and extensive necrosis that required multiple surgical debridements. When necrosis progressed despite debridement, bilateral above-knee amputation of the legs was performed. Once new lesions stopped appearing, the patient was discharged home. Two months later, she had a recurrence related to cocaine use. To the best of our knowledge, this is only the second reported case of levamisole-induced vasculitis that required above-knee amputation.
\end{abstract}

Keywords: Levamisole, Cutaneous vasculitis, Retiform purpura, Leukocytoclastic vasculitis

\section{Background}

According to July 2009 estimates, 69\% of the cocaine seized by the US Drug Enforcement Administration (DEA) is adulterated with levamisole [1,2]. Levamisole is a veterinary antihelminthic agent that has recently been linked to vasculitis and neutropenia in people with cocaine use [3,4]. We describe a cocaine user with levamisole-induced necrosis of the skin, soft tissue, and cartilage resulting in nasal amputation, earlobe necrosis, and bilateral above-knee amputation (AKA). To the best of our knowledge, this is only the second case of levamisole-induced vasculitis requiring above-knee amputation to be reported in the English language

\footnotetext{
* Correspondence: narora@med.wayne.edu

Department of Internal Medicine, Wayne State University School of Medicine, Detroit Medical Center, 4201 Saint Antoine Street, Detroit 48201MI, USA
}

literature, and it is also one of the first reported cases with laboratory confirmation of levamisole exposure.

\section{Case presentation}

A 44-year-old African American woman with history of hypertension and asthma presented to the hospital with a complaint of a painful rash on her extremities of 23 months' duration. The rash first appeared on her upper extremities and then progressed to her legs, cheeks, nose, and earlobes. She denied a history of fever, weight loss, alopecia, dry mouth, oral ulcers, painful red eyes, photosensitivity, myalgia, arthralgia, joint swelling, dysphagia, miscarriages, or blood clots. The patient had a chronic history of crack cocaine use and a smoking history of five pack-years. On examination, her vital signs were stable. Skin examination revealed erythematous maculopapular purpuric lesions on her nose, 


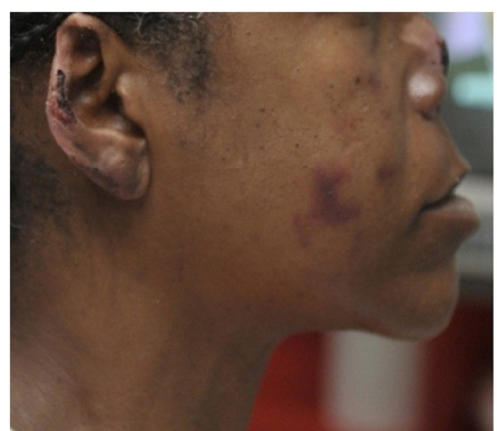

Figure 1 Purpuric lesions and necrosis of both earlobes.

cheeks, and earlobes with central blackish discoloration (Figures 1 and 2). She had several large violaceous plaques and flaccid bullae on her upper and lower extremities and a stage-II ulcer on the medial surface of her right ankle with some serosanginuous discharge. Other physical examination results were normal.

Laboratory investigations revealed leukopenia with a white blood cell count (WBC) of 2,600 cells $/ \mu \mathrm{L}$, neutropenia with an absolute neutrophil count (ANC) of 900 cells $/ \mu \mathrm{L}$, an elevated erythrocyte sedimentation rate (ESR) of $47 \mathrm{~mm} /$ hour, presence of lupus anticoagulant, low complement component 3 (C3) $(85 \mathrm{mg} / \mathrm{dL})$, a normal coagulation profile, absence of antinuclear antibody (ANA), absence of cardiolipin antibody, presence of perinuclear anti-neutrophil cytoplasmic antibody (p-ANCA) against myeloperoxidase (MPO), and absence of antiproteinase 3 (anti-PR3) antibody.

Her urine toxicology screen was positive for cocaine, and gas chromatography-mass spectrometry (GCMS) was positive for levamisole. Punch biopsy of the skin from involved areas showed leukocytoclastic vasculitis with angiocentric infiltrates of mixed inflammatory cells and small vessel thrombosis with multiple fibrin thrombi in the lumen of the vessels (Figures 3 and 4).

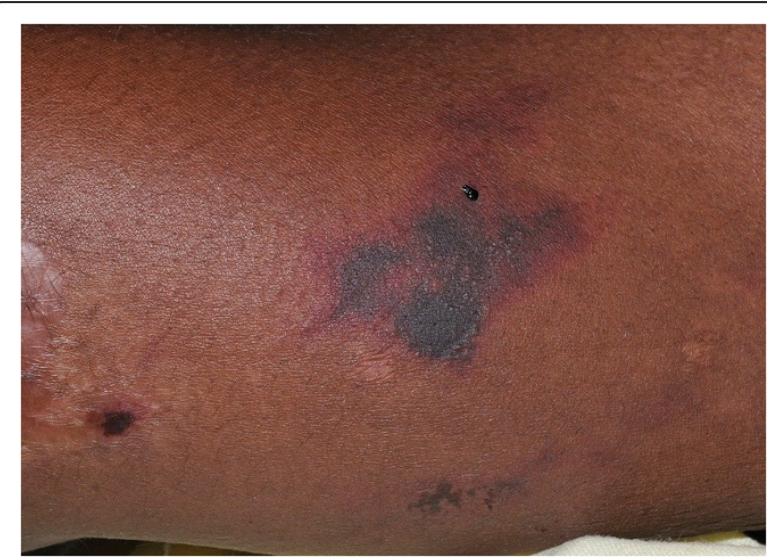

Figure 2 Purpuric patches on extremities.
Lesions on the lower extremities continued to expand, and those on nose, left cheek, and ears became necrotic. Large lower extremity bullae ruptured, leading to wound infection and septicemia with Staphylococcus aureus, Enterobacter cloacae, and Morganella morganii, which were treated with broad-spectrum antibiotics. At this point, skin involvement was estimated to be $35 \%$ of the total body surface area, and the patient was managed in a burn unit. Extensive and infected necrosis of the lower extremities required fascial excision of the dead skin and subcutaneous tissue. The patient underwent two further surgical debridements. Despite this, necrosis progressed, and attempts at nonoperative management were not successful. Eventually, bilateral AKA of the legs above the areas of necrotic skin was performed to control the spread of nonhealing necrotic wounds. The decision to proceed with bilateral AKA was based on the presence of a significant degree of necrosis of leg muscles and the poor functional prognosis for the lower extremities, even if the nonhealing wounds eventually closed with local

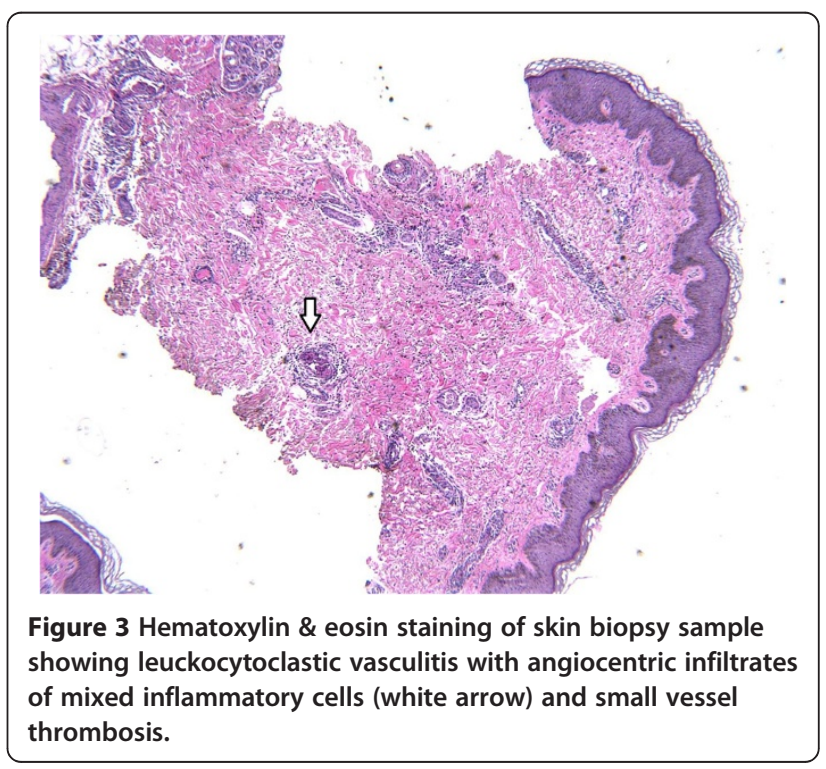




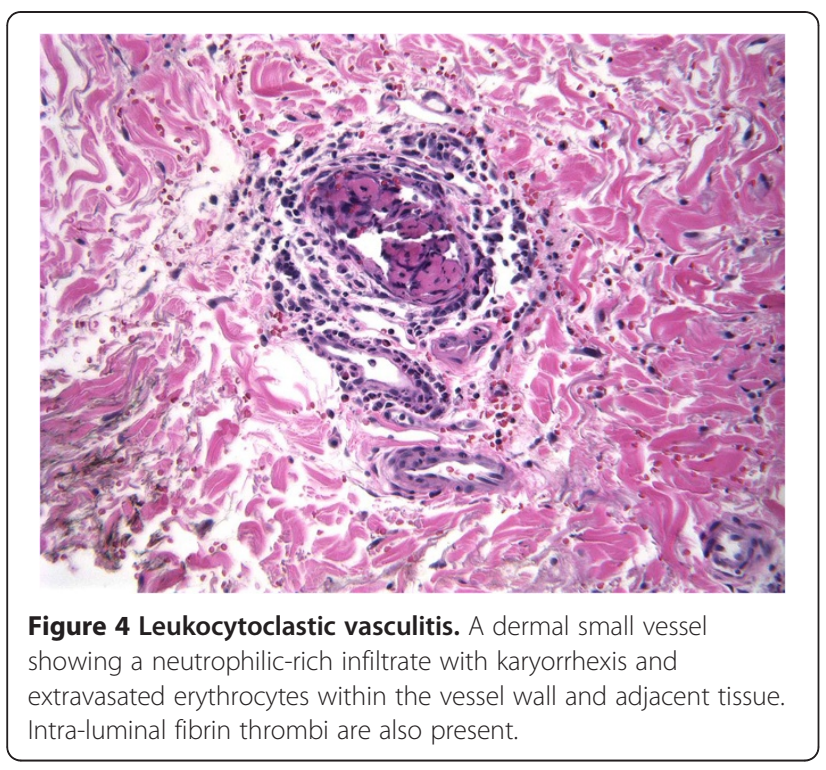

wound care or skin grafts. Necrotic lesions on the nose led to its self-amputation (Figure 5). The patient's pain was controlled with morphine (patient controlled analgesia). New lesions stopped appearing a few days following surgery, and she was discharged home with a prescription of gabapentin for neuropathic pain.

Two months later, the patient was readmitted with new painful necrotic lesions on the amputated stumps (Figure 6). She admitted to cocaine use three days prior to this admission. She was treated with intravenous methylprednisolone for three days followed by tapering doses of oral prednisone for seven days. Her pain and lesions improved significantly, and she was discharged home with a plan to follow up with the hospital's plastic surgery service for nose reconstruction.

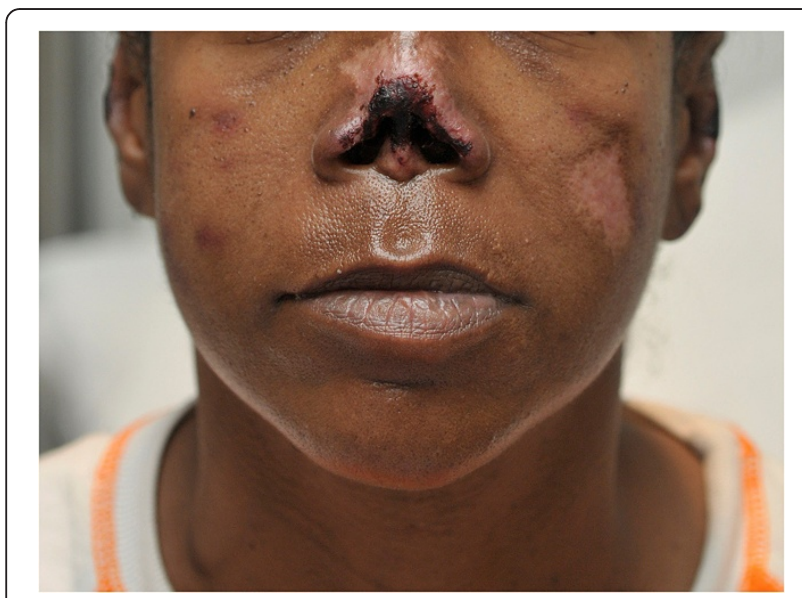

Figure 5 Necrotic lesions on the nose that eventually led to nasal septal destruction and self-amputation.

\section{Discussion}

Levamisole is a veterinary antihelminthic agent currently used to treat worm infestations in cattle, sheep, and pigs [5]. In the past, it was used in humans to treat various autoimmune disorders and cancers because of its immunomodulatory properties [5]. Levamisole-induced vasculitis (LIV) was first reported in a rheumatoid arthritis patient in 1978 [6]. Since 2009, levamisole has also been linked to cutaneous vasculitis in people who use cocaine.

To the best of our best knowledge, 32 cases of LIV in patients with cocaine use have been reported to date [3,4,7-22]. Clinical features, laboratory results, skin biopsy findings, and the treatment of these patients are summarized in Tables 1, 2 and 3. Of the 32 patients described, only eight had levamisole exposure confirmed by urinalysis or GCMS, although other authors speculated on this link based on the presence of levamisole in approximately $69 \%$ of the cocaine entering the United States. Among all the reported cases, only one (published twice by different authors, i.e., Ching et al. [15] and Mouzakis et al. [16]) had extensive necrosis requiring AKA. The patient was a 54-year-old man positive for p-ANCA who developed fever, agranulocytosis, and extensive skin necrosis following heavy intranasal cocaine use. Necrosis was present on more than $50 \%$ of his total body surface area, requiring thorough wound debridement, skin grafting, and left-sided AKA. Unlike our patient, AKA in this case was unilateral, and levamisole exposure was not confirmed by GCMS since the patient presented late after the likely exposure. The authors speculated that levamisole exposure was probable based on the patient's clinical presentation and history of cocaine use. Our patient represents the most extensive confirmed case of LIV with involvement of 35\% of her total body surface area.

Levamisole was an FDA-approved drug but was withdrawn for use in humans in the USA in 1999 due to reports of serious adverse effects such as agranulocytosis, thrombocytopenia, arthritis, and LIV [23-26]. However, it is still available for animal use in the United States, Canada, and South America [26]. In the presence of alternative and more efficacious veterinary antihelminthics, such as ivermectin $[27,28]$, the reasons for continued availability of levamisole for animal use are poorly understood, especially in light of the emerging data on the potential dangers of its addition to cocaine.

The practice of adulterating cocaine with levamisole has increased significantly in recent years [26,29]. Several theories exist to explain the reasons for adulterating cocaine with levamisole. One explanation may be levamisole's ability to potentiate the psychotropic effects of cocaine [26]. Stimulant effects of cocaine are mediated by the blockage of presynaptic reuptake pumps for the monoamine neurotransmitters 

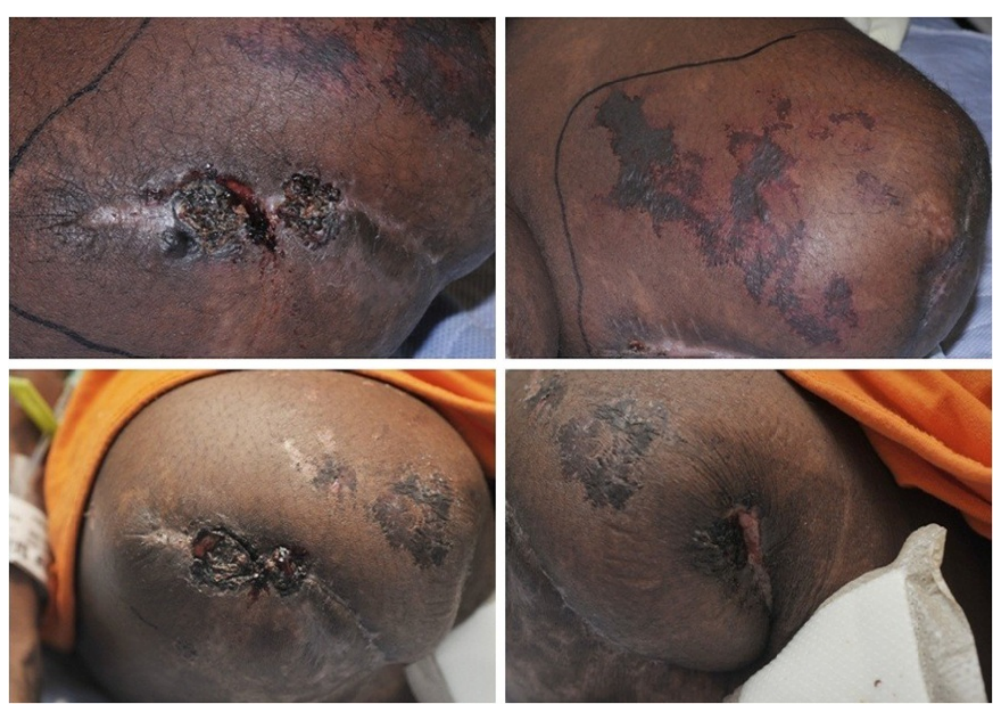

Figure 6 Recurrent purpuric and necrotic lesions on the amputation stumps with repeat use of cocaine.

dopamine, norepinephrine, and serotonin in the central and peripheral nervous systems leading to their enhanced activity [30,31]. Animal data suggest that levamisole may have an inhibitory action on monoamine oxidase and catechol-O-methyltransferase, the enzymes that metabolize catecholamine neurotransmitters [26]. Therefore, levamisole may potentially inhibit the degradation of these stimulatory neurotransmitters, prolonging the duration of their action and adding to the reuptake-inhibition effect of cocaine. Clinically, this may result in enhanced psychotropic effects [26]. Antihelminthic properties of levamisole are due to its species-specific agonistic action at nicotinic acetylcholine receptors of the muscle cells of nematodes [32]. Cocaine may also act on the nicotinic acetylcholine receptors of humans, resulting in increased dopaminergic reuptake inhibition and glutamatergic activity [33]. Although unlikely due to species-specific action of levamisole, it is theoretically possible that cocaine and levamisole may have a synergistic action at nicotinic acetylcholine receptors resulting in increased nicotinic and dopaminergic effects [26]. Also, studies in horses have suggested that levamisole may get metabolized to aminorex, an amphetamine derivative with stimulant effects similar to cocaine and amphetamine [34]. Other possible explanation for using levamisole as a cocaine adulterant may be its use as a "marker" or "signature" compound by manufacturers to trace its market distribution [26]. Some media reports suggest that levamisole is used as a cutting agent for cocaine because it adds bulk and weight to powdered crack cocaine while retaining the appearance and look of pure cocaine, and it also has the ability to pass cocaine purity tests used by drug dealers. Levamisole-induced cutaneous vasculitis has been reported both with smoked crack cocaine [17] and inhaled powdered cocaine [21], indicating that both are adulterated with levamisole.

In addition to levamisole, other commonly used cocaine adulterants include local anesthetics, sugars, stimulants (such as caffeine, ephedrine, phenylpropanolamine, and amphetamines); toxins (such as quinine and strychnine); and inert compounds [35]. Among these cocaine adulterants, only stimulants have been associated with vasculitis upon chronic use. Unlike LIV, the vasculitis associated with chronic stimulant use is usually cerebral or systemic in distribution [35].

As LIV is usually associated with the generation of autoantibodies such as p-ANCA, ANA, and lupus anticoagulant, it may be difficult to differentiate it from autoimmune disorders such as Wegener's granulomatosis and other small-vessel vasculitides. The exact pathogenic mechanisms responsible for the formation of these autoantibodies remain elusive. Recent reports have suggested that, due to its ability to act as a hapten, levamisole may cause increased formation of antibodies to various antigens and therefore lead to an immune response involving the opsonization and eventual destruction of the leukocytes [33].

Before the recognition of levamisole as an adulterant in the cocaine supply, cocaine alone was associated with an p-ANCA-positive pseudovasculitis in some previous reports [36]. Although clinical presentation and laboratory findings of pseudovasculitis may be similar to true vasculitis, biopsy specimens in pseudovasculitis patients do not reveal the typical histopathologic findings seen in patients with true vasculitis [36]. Moreover, there is a possibility that these cocaine-related pseudovasculitis 
Table 1 Clinical features of all reported cases of levamisole-induced cutaneous vasculitis in patients with cocaine use

\begin{tabular}{|c|c|c|}
\hline Authors & Age/Sex & Clinical findings \\
\hline \multirow[t]{4}{*}{ Gross RL et al. [3] } & 50 years $/ \mathrm{M}$ & Retiform pupuric plaques with ulceration on earlobes/helix and lower extremities \\
\hline & 42 years $/ \mathrm{M}$ & Reticulate pink/purple erythematous eruptions on legs, chest, arms, and back \\
\hline & 42 years/F & Violaceous papules, reticular-purpuric plaques on arms, breasts, legs, and ears \\
\hline & 59 years/F & Purpuric, necrotic plaques and bullae on face, ears, arms, right cheek, chest, and axilla \\
\hline \multirow[t]{5}{*}{ Ullrich K et al. [4] } & 45 years $/ \mathrm{M}$ & Painful necrotic purpura and skin nodules on extremities and ears \\
\hline & 49 years/F & Painful purpura on extremities, trunk, and earlobes \\
\hline & 27 years/F & Painful purpura on lower extremities, arthralgia \\
\hline & 29 years $/ F$ & Purpuric lesion with central necrosis on left foot, purpuric lesions on both ears \\
\hline & 55 years/F & Episodic rash on face, trunk, and extremities \\
\hline \multirow[t]{2}{*}{ Bradford M et al. [7] } & 57 years/F & Purpuric plaques with central necrosis on cheeks and earlobes \\
\hline & 22 years/F & Erythematous plaques with central necrosis on face, ears, legs, thighs, and buttocks \\
\hline Buchanan JA et al. [8] & Not specified/M & Purple discoloration on left upper arm and right second toe, bilateral necrosis of ears \\
\hline \multirow[t]{2}{*}{ Walsh NMG et al. [9] } & 39 years/F & Retiform purpura, hemorrhagic bullae on legs, trunks, and buttocks \\
\hline & 49 years/F & Retiform purpura on chest, limbs, bilateral nasal mucosal ulcers \\
\hline \multirow[t]{2}{*}{ Waller JM et al. [10] } & 38 years/F & Retiform purpura with central necrosis on earlobes, cheeks, breast, extremities \\
\hline & 43 years/F & $\begin{array}{l}\text { Retiform purpura with central necrosis on legs, arms, and pinna; I } \\
\text { ivedo racemosa, splinter hemorrhages }\end{array}$ \\
\hline \multirow[t]{2}{*}{ Farhat EK et al. [11] } & 43 years/F & Retiform purpura with central necrosis on bilateral lower extremities \\
\hline & 41 years/F & Painful retiform purpuric patches on thighs, buttocks, trunk, upper extremities, and nasal tip \\
\hline Click J [12] & 29 years/F & Calf ulcerations, retiform purpura \\
\hline Geller L et al. [13] & 50 years/F & Stellate purpura with central necrosis on upper extremities, ears, back, and breasts \\
\hline Han C et al. [14] & 52 years/F & Painful retiform purpura with ulceration on arms, legs, nasal tip, cheeks, ears \\
\hline $\begin{array}{l}\text { Ching J et al. [15]/ } \\
\text { Mouzakis J et al. [16] }\end{array}$ & 54 years/F & $\begin{array}{l}\text { Purpuric patches and plaques on legs, upper extremities, perinasal area, } \\
\text { anterior trunk, face, and ears }\end{array}$ \\
\hline \multirow[t]{2}{*}{ Jacob RS et al. [17] } & 41 years/F & Tender purpuric patches and plaques on ears, legs, upper extremities, back, toes, and soles \\
\hline & 48 years/F & Tender purpuric patches and plaques on ears and left cheek \\
\hline Lung D et al. [18] & 44 years $/ F$ & Stellate, purpuric macules and plaques with central necrosis on legs, abdomen, and face \\
\hline Zwang NA et al. [19] & 52 years $/ \mathrm{M}$ & $\begin{array}{l}\text { Violaceous retiform papules/plaques on arms, legs, back, trunk, scalp, buttocks, } \\
\text { fingers, foot, and ear }\end{array}$ \\
\hline \multirow[t]{4}{*}{ Chung C et al. [20] } & 46 years/F & Purpura and necrosis on bilateral ears, cheeks, and upper and lower extremities \\
\hline & 46 years/F & Bilateral ear necrosis, diffuse retiform purpura with necrosis on neck, trunk, and extremities \\
\hline & 37 years/M & Tender bilateral ear purpura and necrosis, diffuse retiform purpura on trunk and extremities \\
\hline & 50 years/M & Tender purpura and necrosis on both ears, purpura and bullae on trunk and extremities \\
\hline Jenkins J et al. [21] & 47 years $/ \mathrm{M}$ & Painful retiform purpura with necrotic center on legs, ears, cheek, tongue, trunk, and genitalia \\
\hline John S et al. [22] & 52 years/F & Painful violaceous plaques and flaccid bullae on right ankle, legs, left arm, and left breast \\
\hline Arora et al. [current report] & 44 years $/ F$ & Erythematous purpuric lesions with central necrosis on nose, cheeks, earlobes, and extremities \\
\hline
\end{tabular}

cases were actually caused by unrecognized contamination with levamisole.

Adulteration of the majority of the cocaine supply entering United States with levamisole is concerning, especially in view of the high frequency of cocaine use in this country. According to the August 2005 National Survey on Drug Use and Health (NSDUH) Report, more than 5.9 million (2.5\%) persons aged 12 years or older used cocaine in 2002-2003 [37].
Based on published reports, Levamisole-induced cutaneous vasculitis in cocaine users is more commonly seen in women [3]. Clinical features commonly include a tender purpuric rash in a retiform/reticular distribution with or without necrosis [3]. In addition to leukopenia and neutropenia, laboratory results are usually positive for different types of auto-antibodies such as c-ANCA, p-ANCA, ANA, and lupus anticoagulant [3]. Recurrence or exacerbation of skin lesions with cocaine use have 
Table 2 Laboratory findings of all reported cases of levamisole-induced cutaneous vasculitis in patients with cocaine use

\begin{tabular}{|c|c|c|c|}
\hline Authors & Age/Sex & $\begin{array}{c}\text { Leucopenia and/or } \\
\text { Neutropenia }\end{array}$ & Antibodies present \\
\hline \multirow[t]{4}{*}{ Gross RL et al. [3] } & 50 years $/ \mathrm{M}$ & Yes, WBC $-3,300 / \mu \mathrm{L}$, ANC $-2400 / \mu \mathrm{L}$ & p-ANCA, ANA, LAC, c-ANCA, anti-ds-DNA \\
\hline & 42 years/M & Yes, WBC $-3,200 / \mu \mathrm{L}, \mathrm{ANC}-800 / \mu \mathrm{L}$ & p-ANCA, ANA, LAC, c-ANCA, IgM ACL \\
\hline & 42 years/F & No & p-ANCA, c-ANCA, ANA \\
\hline & 59 years/F & No & p-ANCA, ANA, anti-RNP \\
\hline \multirow[t]{5}{*}{ Ullrich K et al. [4] } & 45 years/M & 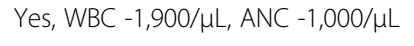 & p-ANCA, c-ANCA, ANA, IgM ACL \\
\hline & 49 years/F & Yes, WBC -3,500/ $\mu \mathrm{L}$, ANC - 0 (zero) & ANA, C-ANCA \\
\hline & 27 years/F & Yes, WBC $-1,800 / \mu \mathrm{L}$, ANC $-400 / \mu \mathrm{L}$ & p-ANCA, c-ANCA, IgM ACL, ANA \\
\hline & 29 years/F & No & p-ANCA, c-ANCA, IgM ACL, ANA \\
\hline & 55 years/F & 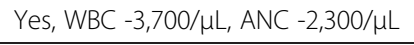 & p-ANCA, c-ANCA, IgM ACL \\
\hline \multirow[t]{2}{*}{ Bradford M et al. [7] } & 57 years/F & Yes, ANC -500/pL & p-ANCA, IgM ACL \\
\hline & 22 years/F & Yes, ANC $<1,000 / \mu \mathrm{L}$ & p-ANCA, IgM ACL \\
\hline Buchanan JA et al. [8] & Not specified/M & Yes, WBC $-1,900 / \mu \mathrm{L}$ & Not reported \\
\hline \multirow[t]{2}{*}{ Walsh NMG et al. [9] } & 39 years/F & No & p-ANCA, c-ANCA, ANA, LAC, anti-HNE \\
\hline & 49 years/F & 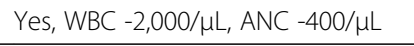 & p-ANCA, c-ANCA, ANA, anti-HNE \\
\hline \multirow[t]{2}{*}{ Waller JM et al. [10] } & 38 years/F & Yes, ANC - $550 / \mu \mathrm{L}$ & p-ANCA, c-ANCA, LAC \\
\hline & 43 years/F & Yes, ANC - $560 / \mu \mathrm{L}$ & p-ANCA, IgM ACL, LAC, anti-ds-DNA, \\
\hline \multirow[t]{2}{*}{ Farhat EK et al. [11] } & 43 years/F & No & p-ANCA \\
\hline & 41 years/F & No & p-ANCA, IgM ACL \\
\hline Click J [12] & 29 years/F & No & p-ANCA, c-ANCA, ANA \\
\hline Geller L et al. [13] & 50 years/F & 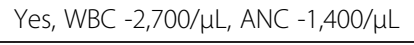 & $\mathrm{p}-\mathrm{ANCA}, \operatorname{lgM} \mathrm{ACL}$ \\
\hline Han C et al. [14] & 52 years/F & Yes, WBC $-2,400 / \mu \mathrm{L}$, ANC $-1,400 / \mu \mathrm{L}$ & p-ANCA, c-ANCA, IgM ACL \\
\hline Ching J et al. [15]/Mouzakis J et al. [16] & 54 years/F & 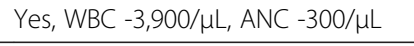 & p-ANCA, IgM ACL \\
\hline \multirow[t]{2}{*}{ Jacob RS et al. [17] } & 41 years/F & 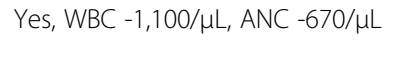 & $\begin{array}{l}\text { p-ANCA, c-ANCA, IgM ACL, } \\
\text { ANA, anti-ds-DNA,anti-HNE }\end{array}$ \\
\hline & 48 years/F & 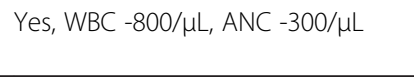 & $\begin{array}{l}\text { p-ANCA, c-ANCA, IgM ACL, ANA, } \\
\text { anti-ds-DNA,anti-HNE }\end{array}$ \\
\hline Lung D et al. [18] & 44 years/F & 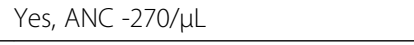 & Not reported \\
\hline Zwang NA et al. [19] & 52 years/M & No & $\begin{array}{l}\text { p-ANCA, c-ANCA, IgM ACL, ANA, LAC, } \\
\text { anti-HNE,anti-ds-DNA, }\end{array}$ \\
\hline \multirow[t]{4}{*}{ Chung C et al. [20] } & 46 years/F & No & p-ANCA, c-ANCA, IgM ACL \\
\hline & 46 years/F & Yes, WBC and ANC not specified & p-ANCA, c-ANCA, IgM ACL \\
\hline & 37 years/M & No & $\mathrm{p}$-ANCA, ANA \\
\hline & 50 years/M & No & p-ANCA, ANA \\
\hline Jenkins J et al. [21] & 47 years/M & No & p-ANCA \\
\hline John S et al. [22] & 52 years/F & 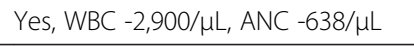 & p-ANCA +,anti ds-DNA+ \\
\hline Arora et al. [current report] & 44 years/F & Yes, WBC $-2,600 / \mu \mathrm{L}$, ANC $-900 / \mu \mathrm{L}$ & p-ANCA+, LAC+ \\
\hline
\end{tabular}

Abbreviations: $M=$ male, $F=$ female, $W B C=$ white blood cell count, $A N C=$ absolute neutrophil count, $p$-ANCA = perinuclear anti-neutrophil cytoplasmic antibody, $c-A N C A=$ cytoplasmic anti-neutrophil cytoplasmic antibody, IgM $A C L=$ immunoglobulin $-M$ anticardiolipin antibody, $A N A=$ antinuclear antibody, $L A C=$ lupus anti-coagulant, anti-HNE = anti-human neutrophil elastase antibody, anti-ds-DNA=anti-double-stranded deoxyribonucleic acid antibody, anti-RNP = anti-ribonucleoprotein antibody.

been reported in some cases. Skin biopsy shows either a mixed pattern of leukocytoclastic and thrombotic vasculitis or an isolated thrombotic vasculopathy [3].

Cessation of cocaine use and supportive care of LIVrelated skin lesions lead to resolution of symptoms in most of the cases. Steroids have been used in a significant number of previously reported cases with a variable response. The recurrent lesions in our patient improved significantly after intravenous methylprednisolone. However, due to the risk of increased susceptibility to superimposed infections, steroid use should be limited to more severe cases that fail to respond to 
Table 3 Skin biopsy findings, treatment, and response to treatment information of all reported cases of levamisole-induced cutaneous vasculitis

\begin{tabular}{|c|c|c|c|c|}
\hline Authors & Age/Sex & Pathology & Treatment & Response \\
\hline \multirow[t]{4}{*}{ Gross RL et al. [3] } & 50 years $/ M$ & Vasculitis, thrombosis, necrosis & $\begin{array}{l}\text { Oral prednisone, } \\
\text { surgical debridement }\end{array}$ & $\begin{array}{l}\text { Lesions remained stable, developed auditory } \\
\text { hallucinations \& superinfection }\end{array}$ \\
\hline & 42 years $/ M$ & Small-vessel vasculitis & Supportive care & Lesions improved without any intervention \\
\hline & 42 years/F & Lekocytoclastic vasculitis, thrombosis & Oral prednisone & Lesions improved in one week \\
\hline & 59 years/F & Small-vessel vasculitis, thrombosis & Oral prednisone & Lost to follow-up \\
\hline \multirow[t]{5}{*}{ Ullrich K et al. [4] } & 45 years/M & Not reported & Oral prednisone & $\begin{array}{l}\text { Initially improved, but symptoms recurred with } \\
\text { attempts to taper the steroid dose }\end{array}$ \\
\hline & 49 years/F & $\begin{array}{l}\text { Thrombosis, perivascular neutrophils, } \\
\text { and karyorrhetic debris }\end{array}$ & Supportive, G-CSF & Resolution of lesions with abstinence from cocaine \\
\hline & 27 years/F & Lekocytoclastic vasculitis, thrombosis & Oral prednisone & $\begin{array}{l}\text { Lesions resolved with abstinence, arthralgia and } \\
\text { neutropenia improved rapidly with prednisone }\end{array}$ \\
\hline & 29 years/F & Not reported & Supportive care, oral steroids & $\begin{array}{l}\text { Lesions resolved with abstinence, septal perforation \& } \\
\text { arthralia improved with steroids }\end{array}$ \\
\hline & 55 years/F & Lekocytoclastic vascultis, thrombosis & Steroids, cyclophosphamide & Rapid resolution of lesions \\
\hline \multirow[t]{2}{*}{ Bradford M et al. [7] } & 57 years/F & Intravascular thrombosis, no vasculitis & Filgrastim for neutropenia & $\begin{array}{l}\text { Lesions resolved spontaneously, neutropenia } \\
\text { improved with filgrastim }\end{array}$ \\
\hline & 22 years/F & Leucocytoclastic vasculitis, thrombosis & Steroids & Lesions and neutropenia improved rapidly \\
\hline Buchanan JA et al. [8] & Not specified/M & Not done & $\begin{array}{l}\text { Subcutaneous phentolamine } \\
\text { to both ears }\end{array}$ & No improvement \\
\hline \multirow[t]{2}{*}{ Walsh NMG et al. [9] } & 39 years/F & Thrombosis, leucocytoclastic vasculitis & $\begin{array}{l}\text { Anticoagulation, skin } \\
\text { debridement and grafting }\end{array}$ & $\begin{array}{l}\text { No new lesions with discontinuation of cocaine, skin } \\
\text { lesions healed after multiple full thickness skin grafts }\end{array}$ \\
\hline & 49 years/F & Thrombosis, no evidence of vasculitis & Supportive care & Lesions improved, recurrences with cocaine use \\
\hline \multirow[t]{2}{*}{ Waller JM et al. [10] } & 38 years $/ F$ & Leukocytoclastic vasculitis, thrombosis & Supportive care & Lesions improved, recurrences with cocaine use \\
\hline & 43 years $/ F$ & Thrombosis of dermal vessels & Supportive care & Lesions improved, recurrences with cocaine use \\
\hline \multirow[t]{2}{*}{ Farhat EK et al. [11] } & 43 years $/ F$ & Extensive thrombosis, no vasculitis & Supportive care & Not specified \\
\hline & 41 years/F & Thrombosis with no vasculitis & Not specified & Not specified \\
\hline Click J [12] & 29 years/F & $\begin{array}{l}\text { Subepidermal bullous dermatitis, } \\
\text { lymphocytic perivascular infiltrate }\end{array}$ & Skin grafts & Lesions were healing well after 4 months \\
\hline Geller L et al. [13] & 50 years/F & Lecocytoclastic vasculitis, thrombosis & Not specified & Not specified \\
\hline Han C et al. [14] & 52 years/F & Thrombotic vasculopathy, no vasculitis & $\begin{array}{l}\text { Steroids (iv \& oral), dalteparin, } \\
\text { warfarin }\end{array}$ & $\begin{array}{l}\text { Lesions and neutropenia improved, had recurrences in } \\
\text { with repeat cocaine use, which improved with } \\
\text { oral prednisone }\end{array}$ \\
\hline $\begin{array}{l}\text { Ching J et al. [15]/ } \\
\text { Mouzakis J et al. [16] }\end{array}$ & 54 years/F & $\begin{array}{l}\text { Small vessel thrombosis, perivascular } \\
\text { mononuclear infiltrates }\end{array}$ & $\begin{array}{l}\text { IV steroids, left AKA, } \\
\text { skin debridement, allografts }\end{array}$ & $\begin{array}{l}\text { Developed extensive skin necrosis requiring } \\
\text { debridement and skin grafts }\end{array}$ \\
\hline \multirow[t]{2}{*}{ Jacob RS et al. [17] } & 41 years/F & $\begin{array}{l}\text { Epidermal necrosis, vascular thrombosis, } \\
\text { leukocytoclasis }\end{array}$ & Oral prednisone & Resolution of the majority of the patient's lesions \\
\hline & 48 years/F & $\begin{array}{l}\text { Lymphocytic infiltrate, occlusive vasculopathy, } \\
\text { neovascularization }\end{array}$ & Oral prednisone & Lesions improved \\
\hline
\end{tabular}


Table 3 Skin biopsy findings, treatment, and response to treatment information of all reported cases of levamisole-induced cutaneous vasculitis (Continued)

\begin{tabular}{|c|c|c|c|c|}
\hline Lung D et al. [18] & 44 years/F & Extensive thrombotic vasculopathy & Not specified & Not specified \\
\hline Zwang NA et al. [19] & 52 years/M & Leukocytoclastic vasculitis & Oral prednisone & Lesions healed completely in 3 weeks \\
\hline \multirow[t]{4}{*}{ Chung C et al. [20] } & 46 years $/ F$ & Small-vessel vascultits with thrombosis & Steroids & Initial improvement, lost to follow-up \\
\hline & 46 years $/ F$ & Multiple Intravascular thrombi & IV methyl-prednisolone & Gradual improvement initially, lost to follow-up \\
\hline & 37 years $/ \mathrm{M}$ & Leucocytoclastic vasculitis & Supportive & Rapid improvement of skin lesions \\
\hline & 50 years $/ \mathrm{M}$ & Leucocytoclastic vasculitis, panniculitis & Supportive, antibiotics & Rapid improvement of skin lesions \\
\hline Jenkins J et al. [21] & 47 years $/ M$ & Leucocytoclastic vascultits, occlusive vasculopathy & $\begin{array}{l}\text { Oral \& topical steroids, aspirin, } \\
\text { pentoxifylline }\end{array}$ & Lesions resolved over 3 months \\
\hline John S et al. [22] & 52 years/F & Thrombotic vasculopathy, no vasculitis & Supportive, surgical debridement & $\begin{array}{l}\text { Had new lesions with repeat cocaine use and necrotic } \\
\text { ulceration of old lesions requiring surgical debridement }\end{array}$ \\
\hline Arora et al. [current report] & 44 years/F & Leucocytoclastic vasculitis, thrombosis & $\begin{array}{l}\text { Surgical debridement, } \\
\text { pain control, AKA, IV } \\
\text { methyl-prednisolone for recurrent lesions }\end{array}$ & $\begin{array}{l}\text { Recurrent lesions improved significantly with IV } \\
\text { methylprednisolone }\end{array}$ \\
\hline
\end{tabular}

Abbreviations: $M=$ male, $F=$ female, $A K A=$ above knee amputation, $I V=$ intravenous. 
supportive care. Patients should be educated about the possible adverse effects of future cocaine use. Extensive skin involvement and necrosis may need surgical debridement and skin grafting. As happened in our patient, in extreme cases that involve extensive necrosis, amputation may be required to contain necrosis and infection.

\section{Conclusions}

Adulteration of cocaine with levamisole is widely prevalent in United States. Levamisole may cause cutaneous vasculitis and neutropenia in people with cocaine use. History of cocaine use should be explored in patients presenting with a rash and neutropenia, and testing for levamisole exposure should be performed in selected patients. In cases with extensive involvement, this condition may lead to disfigurement by causing necrosis of skin, soft tissue, and cartilage.

\section{Informed consent}

Written informed consent was obtained from the patient for publication of this case report and all accompanying images. A copy of the written consent is available for review by the Editor-in-Chief of this journal.

\section{Competing interests}

None of the authors has any financial conflicts or competing interests to disclose.

\section{Authors' contributions}

NA conceived of the case report, performed the literature search, and drafted and revised the manuscript. TJ and RB acquired, analyzed, and interpreted the data. SN revised the manuscript. All authors read and approved the final draft.

Received: 26 December 2011 Accepted: 17 September 2012 Published: 24 September 2012

\section{References}

1. Buchanan JA, Heard K, Burbach C, Wilson ML, Dart R: Prevalence of levamisole in urine toxicology screens positive for cocaine in an innercity hospital. JAMA 2011, 305(16):1657-1658

2. Centers for Disease Control and Prevention (CDC): Agranulocytosis associated with cocaine use-four States, March 2008-November 2009. MMWR Morb Mortal Wkly Rep 2009, 58:1381-1385.

3. Gross RL, Brucker J, Bahce-Altuntas A, Abadi MA, Lipoff J, Kotlyar D, Barland $P$, Putterman C: A novel cutaneous vasculitis syndrome induced by levamisole-contaminated cocaine. Clin Rheumatol 2011, 30(10):1385-1392.

4. Ullrich K, Koval R, Koval E, Bapoje S, Hirsh JM: Five consecutive cases of a cutaneous vasculopathy in users of levamisole-adulterated cocaine. J Clin Rheumatol 2011, 17(4):193-196.

5. Amery WK, Bruynseels JP: Levamisole, the story and the lessons. Int Immunopharmacol 1992, 14(3):481-486.

6. Macfarlane DG, Bacon PA: Levamisole-induced vasculitis due to circulating immune complexes. Br Med J 1978, 1(6110):407-408,

7. Bradford M, Rosenberg B, Moreno J, Dumyati G: Bilateral necrosis of earlobes and cheeks: another complication of cocaine contaminated with levamisole. Ann Intern Med 2010, 152(11):758-759.

8. Buchanan JA, Vogel JA, Eberhardt AM: Levamisole-induced occlusive necrotizing vasculitis of the ears after use of cocaine contaminated with levamisole. J Med Toxicol 2011, 7(1):83-84

9. Walsh NMG, Green PJ, Burlingame RW, Pasternak S, Hanly JG: Cocainerelated retiform purpura: evidence to incriminate the adulterant, levamisole. J Cutan Pathol 2010, 37(12):1212-1219.
10. Waller JM, Feramisco JD, Alberta-Wszolek L, McCalmont TH, Fox LP: Cocaine-associated retiform purpura and neutropenia: is levamisole the culprit? J Am Acad Dermatol 2010, 63(3):530-535.

11. Farhat EK, Moorhead TT, Chaffing ML, Douglass MC: Levamisole-induced cutaneous necrosis mimicking coagulopathy. Arch Dermatol 2010, 146(11):1320-1321

12. Click J: Levamisole-induced retiform purpura. J Drug Dermatol 2011, 10(2):217.

13. Geller $L$, Whang TB, Mercer SE, Phelps R: Retiform purpura: a new stigmata of illicit drug use? Dermatol Online J 2011, 17(2):7.

14. Han C, Sreenivasan G, Dutz JP: Reversible retiform purpura: a sign of cocaine use. CMAJ 2011, 183(9):597-600.

15. Ching JA, Smith DJ Jr: Levamisole-induced necrosis of skin, soft tissue, and bone: case report and review of literature. J Burn Care Res 2012, 33(1):1-5.

16. Mouzakis J, Somboonwit C, Lakshmi S, Rumbak M, Sinnott J, Cherpelis B, Keshishian J: Levamisole-induced necrosis of the skin and neutropenia following intranasal cocaine use: a newly recognized syndrome. J Drugs Dermatol 2011, 10(10):1204-1207.

17. Jacob RS, Silva CY, Powers JG, Schieke SM, Mendese G, Burlingame RW, Miller DD, Wolpowitz D, Graber E, Mahalingam M: Levamisole-induced vasculopathy: a report of 2 cases and a novel histopathologic finding. Am J Dermatopathol 2012, 34(2):208-213.

18. Lung D, Lynch K, Agrawal S, Armenian P, Banh K: Images in emergency medicine, adult female with rash on lower extremities. vasculopathic purpura and neutropenia caused by levamisole-contaminated cocaine. Ann Emerg Med 2011, 57(3):307-311.

19. Zwang NA, Van Wagner LB, Rose S: A case of levamisole-induced systemic vasculitis and cocaine-induced midline destructive lesion: a case report. J Clin Rheumatol 2011, 17(4):197-200.

20. Chung C, Tumeh PC, Birnbaum R, Tan BH, Sharp L, McCoy E, Mercurio MG, Craft N: Characteristic purpura of the ears, vasculitis, and neutropenia-a potential public health epidemic associated with levamisole-adulterated cocaine. J Am Acad Dermatol 2011, 65(4):722-725.

21. Jenkins J, Babu K, Hsu-Hung E, Robinson-Bostom L, Kroumpouzos G: ANCApositive necrotizing vasculitis and thrombotic vasculopathy induced by levamisole-adulterated cocaine: a distinctive clinicopathologic presentation. J Am Acad Dermatol 2011, 65(1):14-16.

22. John S, Manda S, Hamrock D: Cocaine-induced thrombotic vasculopathy. Am J Med Sci 2011, 342(6):524-526.

23. Parkinson DR, Cano PO, Jerry LM, Capek A, Shibata HR, Mansell PW, Lewis MG, Marquis G: Complications of cancer immunotherapy with levamisole. Lancet 1977, 1(8022):1129-1132

24. Segal AW, Pugh SF, Levi AJ, Loewi G: Levamisole-induced arthritis in Crohn's disease. Br Med J 1977, 2(6086):555.

25. Laux-End R, Inabenit D, Gerber HA, Bianchetti MG: Vasculitis associated with levamisole and circulating autoantibodies. Arch Dis Child 1996, 75(4):355-356

26. Chang A, Osterloh J, Thomas J: Levamisole: a dangerous new adulterant Clin Pharmacol Ther 2010, 88(3):408-411.

27. McKellar Q, Marriner S, Bogan J: Comparison of ivermectin, oxfendazole and levamisole for use as anthelmintics during the periparturient period in sheep. Vet Rec 1988, 122(23):558-560

28. Hembry FG, Miller JE, Sims D, Rodriguez S, Stagg LC: Efficacy of repeated doses of levamisole, morantel, fenbendazole, and ivermectin against gastrointestinal nematodes in ewes. Am J Vet Res 1986, 47(8):1677-1679.

29. Casale JF, Corbeil EM, Hays PA: Identification of levamisole impurities found in illicit cocaine exhibits. Microgram J 2008, 6(3,4):82-89.

30. Rothman RB, Baumann MH, Dersch CM, Romero DV, Rice KC, Carroll Fl, Partilla JS: Amphetamine-type central nervous system stimulants release norepinephrine more potently than they release dopamine and serotonin. Synapse 2001, 39(1):32-41.

31. Howell LL, Kimmel HL: Monoamine transporters and psychostimulant addiction. Biochem Pharmacol 2008, 75(1):196-217.

32. Martin RJ: Modes of action of anthelmintic drugs. Vet J 1997, 154(1):11-34.

33. Raymon $L P$, Isenschmid DS: Letter to the editor: the possible role of levamisole in illicit cocaine preparations. J Anal Toxicol 2009, 33(9):620-622.

34. Ho EN, Leung DK, Leung GN, Wan TS, Wong AS, Wong CH, Soma LR, Rudy JA, Uboh C, Sams R: Aminorex and rexamino as metabolites of levamisole in the horse. Anal Chim Acta 2009, 638(1):58-68. 
35. Shannon M: Clinical toxicity of cocaine adulterants. Ann Emerg Med 1988, 17(11):1243-1247.

36. Friedman DR, Wolfsthal SD: Cocaine-induced pseudovasculitis. Mayo Clin Proc 2005, 80(5):671-673.

37. Office of Applied Studies (OAS), Substance Abuse and Mental Health Services Administration (SAMHSA): The 2005 National Survey on Drug Use and Health Report; http://www.oas.samhsa.gov/2k5/cocaine/cocaine.pdf.

doi:10.1186/1940-0640-7-19

Cite this article as: Arora et al.: Levamisole-induced leukocytoclastic

vasculitis and neutropenia in a patient with cocaine use:

An extensive case with necrosis of skin, soft tissue, and cartilage.

Addiction Science \& Clinical Practice 2012 7:19.

\section{Submit your next manuscript to BioMed Central} and take full advantage of:

- Convenient online submission

- Thorough peer review

- No space constraints or color figure charges

- Immediate publication on acceptance

- Inclusion in PubMed, CAS, Scopus and Google Scholar

- Research which is freely available for redistribution 